\title{
31. HIGH-RESOLUTION IMAGING OF LAMINATED BIOSILICEOUS SEDIMENTS AND THEIR PALEOCEANOGRAPHIC SIGNIFICANCE (QUATERNARY, SITE 798, OKI RIDGE, JAPAN SEA) ${ }^{1}$
}

\author{
Kurt Andrew Grimm²
}

\begin{abstract}
High-resolution, backscattered-electron microanalysis of finely-laminated biosiliceous sediments from Site 798 reveals thin $(10->250 \mu \mathrm{m})$ laminae containing diverse detrital and biotic components. These include laminae enriched in Chaetoceros resting spores, calcareous nannofossils, and foraminifera, as well as cyclic oscillations between clay-rich and mixed-biosiliceous laminae. Adjacent laminae commonly display substantial contrasts in microfossil diversity and fragmentation, which are attributable to high-frequency variability in planktonic community structure and to biologically-mediated processes of sediment flux and microfossil breakage.

Discrete laminae record single episodes of hemipelagic sedimentation. Comparison of laminae thickness to mean sedimentation rate at Site $798(\approx 12 \mathrm{~cm} / 1000 \mathrm{yr})$ suggests that individual laminae may record annual to subannual episodes of sediment flux. By analogy to data from sediment traps in different settings, I suggest that the observed variations in the composition of some laminae were mediated by meteorological and short-term oceanographic influences upon oceanic fertility, primary productivity, detrital input and bulk sediment flux. In sum, laminated sediments at Site 798 provide a reliable record of very short-duration oceanographic processes during the Quaternary.
\end{abstract}

\section{INTRODUCTION}

Sediment-trap data indicate that the flux of biogenic and associated detrital sediment from the surface mixed layer to the deep sea is highly episodic; furthermore, the surface ocean signal reaches the deep-sea on time scales measured in weeks (Bruland et al., 1989; Allredge and Silver, 1988; Takahashi, 1986; Deuser, 1986; Honjo, 1982). Where sedimentation rates are high and bioturbation is minimal or absent, these sedimentation events may be deposited and preserved as discrete laminae.

The analysis of finely-laminated sediments from settings of high primary productivity have yielded valuable paleoenvironmental and paleoclimatic data (Piskaln and Johnson, 1991; W. Hay, 1990; B. J. Hay, 1988; Anderson et al., 1990, 1987; Soutar and Crill, 1977). However, because these investigations utilized subsampled laminae - thus destroying intergrain and interlamina relationships-and/or low resolution visual analysis (petrography, X-radiography), they resulted in incomplete analysis of the composition and structure of individual hemipelagic laminae. This study provides a detailed documentation of the composition and structure of individual hemipelagic laminae from Site 798.

Kemp (1990) demonstrated that backscattered-electron microscopy (BSEM) on epoxy-impregnated and highly-polished samples of unconsolidated diatomaceous sediment from the Peru margin provided clear definition of sedimentary fabric and lamination style. In this report of the pilot study, I illustrate that BSEM analysis permits recognition of a diversity of lamination types, grain types, and microfossil morphotaxa, at a spatial resolution of $\leq 20 \mathrm{~nm}$, which is $15-20$ times better than achievable through optical microscopy (Krinsley and Manley, 1989). In the discussion, I employ the sediment classification of Mazzullo et al. (1988), as modified by shipboard scientists of Leg 128 (Ingle, Suyehiro, von Breymann, et al., 1990).

\footnotetext{
${ }^{1}$ Pisciotto, K. A., Ingle, J. C., Jr., von Breymann, M. T., Barron, J., et al., 1992. Proc. ODP, Sci. Results, 127/128, Pt. 1: College Station, TX (Ocean Drilling Program).

${ }^{2}$ Earth Sciences Board, University of California, Santa Cruz, Santa Cruz, CA 95064 U.S.A. (Current address: Department of Geological Sciences, University of British Columbia, Vancouver, BC, Canada V6T 2B4.)
}

\section{METHODS}

Twenty-five samples of laminated diatomaceous sediment from the dark, laminated, and diatomaceous half-cycle of the Quaternary sedimentary rhythms encountered at Site 798 were analyzed (Table 1; Föllmi et al., this volume). Sample collection, preparation, and analytical strategy are described in Grimm (this volume). From a single $7 \mathrm{~cm}^{3}$ sample of soft sediment, collected with the advanced piston corer (APC) aboard the ODP drill ship JOIDES Resolution, three subsamples were prepared for visual microanalysis:

1. Petrographic thin sections, for sample reconnaissance (Pl. 1, Fig. 1).

2. Epoxy-impregnated and highly polished sediment slabs; samples of this type comprise the primary focus of this study (Pls. 1-5). These samples were carbon-coated and inserted into a scanning electron microscope equipped for BSEM. BSEM data were recorded directly from the video screen and were captured in Polaroid photographs. In addition, elemental dot maps were generated for large and small fields of view, using an energy-dispersive elemental microanalysis system (EDS). In a similar fashion, individual grains or portions of grains were commonly chemically fingerprinted with an EDS spectral scan (Goldstein et al., 1981), thus facilitating grain and matrix identifications.

3. Dehydrated and ultrasonically-scrubbed sediment blocks; these samples were gold-coated and imaged with an SEM in the secondary electron mode, to document details of specimen topography (Pl. 2, Figs. 3 and 4; and Pl. 4, Fig. 2). The topographic microstructure of clay minerals, biotic grains, and other detritus is preserved in these samples; however, individual laminae were generally not recognizable in SEM. SEM analyses aided recognition of microfossil taxa and matrix composition.

In BSEM images, constituent detrital and biogenic grains were relatively simple to recognize against the black epoxy background. Grain types were differentiated by their morphology and brightness characteristics (Krinsley and Manley, 1989; Pye and Krinsley, 1984; White et al., 1984). Biotic grains such as diatoms, planktonic foraminifers, and benthic foraminifers were easily recognized, and were classified into biotic "morphotaxa" for community analysis (see the following section and Table 2). In addition, relative assessment of carbonate dissolution (foraminifers) and degree of fragmentation, 
Table 1. Location of samples utilized in this study.

$$
\begin{aligned}
& 128-798 \mathrm{~A} \\
& 6 \mathrm{H}-3,131-134 \\
& 10 \mathrm{H}-4,108-111 \\
& 10 \mathrm{H}-4,123-126 \\
& 10 \mathrm{H}-7,4-7 \\
& 10 \mathrm{H}-7,70-73 \\
& 128-798 \mathrm{~B} \\
& 1 \mathrm{H}-6,32-35 \\
& 1 \mathrm{H}-6,43-45 \\
& 1 \mathrm{H}-6,85-88 \\
& 3 \mathrm{H}-1,88-90 \\
& 3 \mathrm{H}-1,93-96 \\
& 9 \mathrm{H}-7,2-4 \\
& 9 \mathrm{H}-7,107-109 \\
& 9 \mathrm{H}-7,110-112 \\
& 10 \mathrm{H}-4,109-111 \\
& 10 \mathrm{H}-4,117-119 \\
& 10 \mathrm{H}-7,19-22 \\
& 10 \mathrm{H}-7,43-45 \\
& 10 \mathrm{H}-7,59-61 \\
& 10 \mathrm{H}-7,78-81 \\
& 128-798 \mathrm{C} \\
& 9 \mathrm{H}-5,132-134 \\
& 9 \mathrm{H}-5,139-141 \\
& 9 \mathrm{H}-7,8-11 \\
& 9 \mathrm{H}-7,73-75 \\
& 9 \mathrm{H}-7,82-85 \\
& 9 \mathrm{H}-7,88-91
\end{aligned}
$$

were made for the biotic components in some samples, in order to make taphonomic interpretations.

Detrital components such as quartz, feldspar, volcanic glass, and clay were distinguished by their grain shape, brightness characteristics, and their elemental fingerprint in EDS scans. Sample alteration during diagenesis, core recovery and sample preparation was also assessed (Table 2; Pl. 4, Fig 3; Pl. 5, Figs. 3 and 4).

\section{RESULTS}

\section{Faunal/Floral Morphotaxa}

The difficulty of confidently identifying of fossil fragments in crosssection is well known (Flügel, 1982; Horowitz and Potter, 1971). Similarly, the identification of microfossil cross-sections in BSEM samples is a complex issue. Consequently, I approach the problem with the concept of two-dimensional (= cross-sectional) morphotaxa.

I define morphotaxa as distinctive biotic grain types, possessing diagnostic morphological characters which clearly distinguish them from other biotic grains. A morphotaxon is a somewhat artificial grouping, since an individual morphotaxon may include more than one genus or species of a specific faunal group. Microfossil morphotaxa were recognized in all of the samples (Table 2).

Despite the limitations, I interpret that morphotaxa have paleobiological significance. I assume that an individual specimen of a recognizable morphotaxon must be systematically related to other members of the same morphotaxon, at a specific, generic, or some higher taxonomic rank. Consequently, I regard the measures of morphotaxic diversity in two-dimensional BSEM images as a proxy for true taxonomic richness.

For biosiliceous forms, I recognize 10 distinct morphotaxa in BSEM images (Table 2). In addition, degree of fragmentation of biosiliceous taxa was assessed (Table 3). Compositional and taphonomic criteria were used to distinguish four discrete associations of biosiliceous floras, within individual laminae ranging from 12 to $1850 \mu \mathrm{m}$ thick (Table 4). I attribute most morphotaxa to diatoms; other biosiliceous taxa such as silicoflagellates, ebridians, and radiolarians were observed in smear slides (Ingle, Suyehiro, von Brey-
Table 2. Recognizable grain types and morphotaxa in BSEM images.

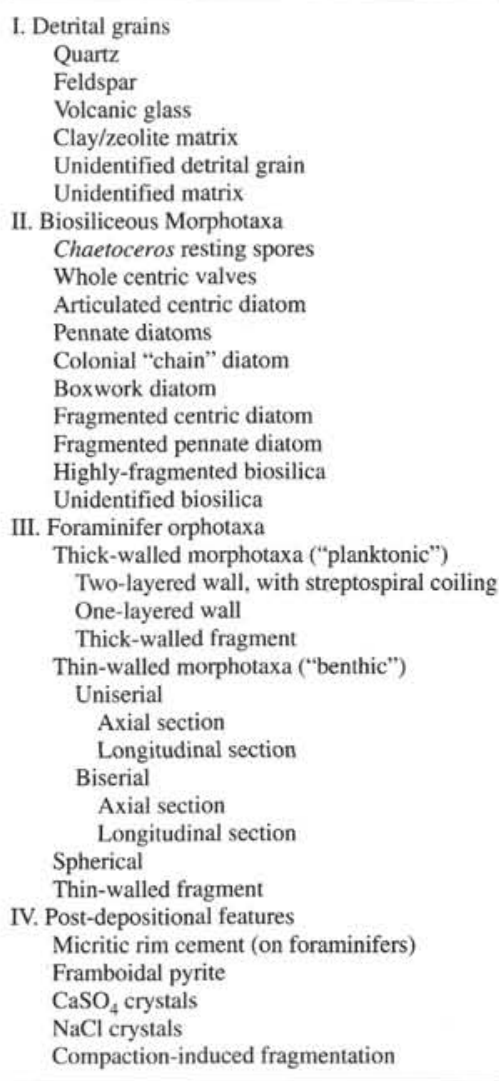

mann, et al., 1990), but have not been confidently identified with BSEM imagery.

For foraminifers, the larger size permits a more detailed assessment of test shape and wall-structure (Grimm, this volume). I have distinguished nine foram morphotaxa (Table 2), from which a subset of planktic vs. benthic morphotaxa was extracted. In general, planktic foraminifers have a uniform distribution in samples within which they occur. This is in contrast to benthic taxa, which are found to occur in specific stratal zones.

\section{Sedimentation Rate}

No clear hiatuses were recognized in shipboard sedimentologic, paleomagnetic, or paleontological investigations. Sedimentation rate at Site 798 appears to be linear and continuous (Ingle, Suyehiro, von Breymann, et al., 1990). Mean sedimentation rate at Site 798 is $\approx 12$ $\mathrm{cm} / 1000$ yr (Ingle, Suyehiro, von Breymann, et al., 1990; see Dunbar et al., this volume; Föllmi et al., this volume).

The thickness of some distinctive lamina types and sedimentary couplets are presented in Figure 1. The thickness of some of these lamina types is comparable to the annual thickness expected from perfectly uniform sedimentation rates $(12 \mathrm{~cm} / 1000 \mathrm{yr}=120 \mu \mathrm{m} / \mathrm{year})$ at Site 798. Consequently, I make the first-order interpretation that many individual laminae may record sediment accumulation on the order of less than or equal to a single year.

I compared the sediment and biotic associations I observed in the samples, with those recorded in published sediment trap studies and in the biological literature. These comparisons are discussed in the following section and are consistent with the working hypothesis that some laminae in diatomaceous, APC-collected sediments at Site 798 
Table 3. Degree of fragmentation of biosilica (arrow is interpretive).

\begin{tabular}{l} 
Biosilica fragmentation: \\
\hline Low \\
Mostly ( $>80 \%$ ) whole forms; clearly \\
recognizable morphotaxa common \\
Moderate
\end{tabular}

Table 4. Distinctive lamination types in BSEM images.

\begin{tabular}{ll}
\hline Lamination type & Interpretation \\
\hline 1. Clay-rich vs. biosiliceous laminae & $\begin{array}{c}\text { 1. Episodes of detrital input vs. } \\
\text { phytoplankton blooms }\end{array}$ \\
$\begin{array}{l}\text { 2. Detrital silt laminae } \\
\text { 2. Gravity-driven event strata } \\
\text { 4. Chaetoceros resting-spore laminae }\end{array}$ & $\begin{array}{l}\text { 3. Productivity variations } \\
\text { 4. Discrete productivity blooms, } \\
\text { laminae encystment and subsequent } \\
\text { mass flux }\end{array}$ \\
$\begin{array}{c}\text { 5. Mixed-biosiliceous laminae that } \\
\text { vary in morphotaxic diversity and } \\
\text { degree of fragmentation }\end{array}$ & $\begin{array}{c}\text { 5. Variations in hydrography, productivity, } \\
\text { and/or taphonomy }\end{array}$ \\
$\begin{array}{c}\text { 6. Foraminifer-rich laminae; } \\
\text { variations between benthic vs. } \\
\text { planktic-rich }\end{array}$ & $\begin{array}{c}\text { 6. Specific changes in surface-water } \\
\text { hydrography and/or bottom water }\end{array}$ \\
$\begin{array}{c}\text { 7. Laminations that lack fine-scale } \\
\text { variability are also present }\end{array}$ & $\begin{array}{c}\text { 7. Reflects absence of seasonality in } \\
\text { sedimentation? }\end{array}$ \\
\hline
\end{tabular}

record very short term - probably annual and seasonal-oscillations in Quaternary oceanic climate.

\section{Lamination Types}

In this section, I provide general descriptions of some conspicuous laminae types, and provide initial interpretations of their paleoceanographic significance (Table 4). Most of the interpretations are based upon BSEM observations, with accessory observations of petrographic thin sections and SEM samples. I acknowledge that some of the interpretations are tentative, however I regard them as the simplest and clearest interpretation of the data.

\section{Detrital-rich/Biosiliceous Alternations}

The most common lamination type in the samples consists of cyclic alternations between fine-grained laminae that lack or contain only sparse biogenic grains with laminae enriched in biosiliceous morphotaxa (Fig. 1; Table 3). Elemental dot mapping of some finegrained laminae reveals that they are enriched in aluminum; the interpretation that $\mathrm{Al}$-enrichment is attributable to clay minerals is substantiated by the presence of clay-rich laminae in petrographic thin section and by the common presence of clay-rich areas within dehydrated sediment cubes imaged with SEM (Grimm, this volume).

Very finely interlaminated clay-rich and diatomaceous laminae at Site 798 are similar to sediments described from the Santa Barbara Basin, California (Soutar et al., 1981). By analogy, I attribute cyclic alternations between clay-rich and biosiliceous laminae at Site 798 as short-term-perhaps seasonal-alternations between pulses of enhanced riverine and/or eolian detrital input with biosiliceous productivity blooms. I concur with Reimers et al., (1990) that the sedimentary record of meteorological seasonality may also be influenced by bottom water changes.

In addition, discrete laminae enriched in silt-sized detritus are present in some diatomaceous intervals; these strata have sharp bases and are normally graded from medium silt to subsilt size. I interpret these coarser interbeds as event deposits, perhaps attributable to deposition from dilute gravity-flows.

\section{Calcareous/Biosiliceous Alternations}

On some freshly-cut core surfaces, submillimeter-scale alternations between green and yellow laminae were observed; smear slide observation revealed abundant diatoms and calcareous nannofossils. The detailed analysis of such an interval is given in Grimm (this volume; Pl. 2, Figs. 1-4). BSEM analysis of these intervals revealed biosiliceous-rich laminae alternating with fine-grained laminae which lack abundant recognizable biogenic grains.

In many cases, elemental dot-mapping with EDS revealed Ca-enrichment of fine-grained laminae. Ca-enrichment of fine-grained sediment may be attributable to Ca-bearing clays, calcic zeolites, micritic carbonate, or enrichment with calcareous nannofossils. Secondary-electron SEM on three samples revealed abundant calcareous nannofossils. I conclude that most of the Ca-enrichment in some fine-grained laminae is attributable to calcareous nannofossils.

The intimate and rhythmic interlamination of biosiliceous and calcareous nannofossil-rich laminae presents an interesting puzzle. In modern environments, diatoms and calcareous nannofossils differ in nutritional requirements for optimal reproductive fecundity (Eppley and Strickland, 1968; Parsons et al., 1984); as a result, diatom-rich sediments are generally regarded as a record of high-fertility surface water masses, whereas calcareous nannofossil-rich sediments record lower oceanic fertility (W. Hay, 1990; Berger et al., 1989). By analogy to the modern Black Sea (B. Hay et al., 1990; B. Hay, 1988; Dean et al., 1991), I regard the alternations between calcareous nannofossilrich clays and biosiliceous clays as a record of high-frequency oscillations in surface layer nutrient availability at Site 798.

\section{Chaetoceros Resting-spore Laminae (and Associated Mixed-Biosiliceous Laminae)}

Laminae greatly-enriched in a subspherical to polygonal morphotaxon, which possesses a siliceous test and spike-like ornament are common in BSEM images (Pl. 3, Figs. 1-4; Pl. 4, Figs. 1 and 2). L. Burckle (pers. comm., 1990) first recognized these forms as Chaetoceros resting-spores; these identifications have been substantiated by K. Buck and D. L. Garrison (pers. comm., 1991).

Chaetoceros resting-spore laminae (CRSL) are distinct from the diatomaceous and diatomaceous mixed-sediment laminae with which they occur (Pl. 3, Figs. 1-4; Pl. 4, Figs. 1-2). CRSL thicknesses range from 35 to $125 \mu \mathrm{m}$; individual resting spores are $\leq 7 \mu \mathrm{m}$ in cross-sectional diameter. In three point counts $(n=150)$ of very well-developed CRSL (Pl. 3; Fig. 3; Pl. 4, Fig. 1), they were composed of $>91 \%( \pm 4 \%)$ Chaetoceros resting spore morphotaxon; less than $7 \%( \pm 4 \%)$ recorded any evidence for fragmentation of the test. Low morphotaxic diversity and a very low degree of fragmentation are characteristic of CRSL.

I did not observe single CRSL in the samples; rather they occur in clusters of three to nine individual CRSL. Individual CRSL are separated by horizons of biosiliceous mixed-sediment and biosiliceous ooze, which are commonly crudely stratified and range from 100 to $220 \mu \mathrm{m}$ thick. Relative to CRSL, the intervening biosiliceous laminae posses higher morphotaxic diversity and higher degree of fragmentation (Tables 2 and 3).

In the modern environment, Chaetoceros resting cells and spores are regarded as a physiological/behavioral response to environmental stress (nitrate depletion, French and Hargraves, 1980; D. Garrison, 

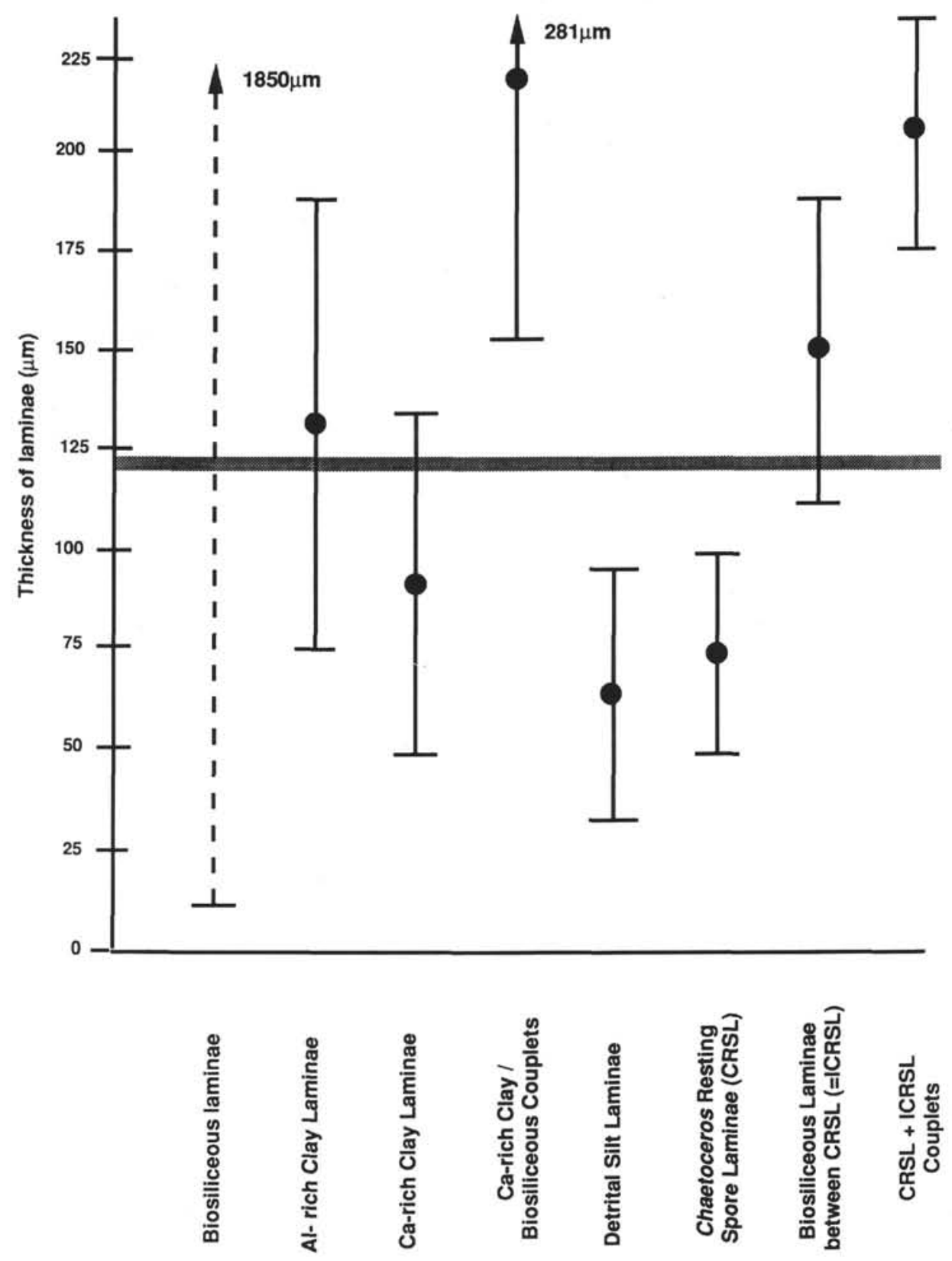

Figure 1. The distribution of measured thicknesses for individual laminae at Site 798; the central dots define mean values; error bars span one standard deviation. The horizontal grey line at $120 \mu \mathrm{m}$ defines the mean annual sediment accumulation for APC-collected sediments at Site 798. For biosiliceous laminae, only the range of measured values is expressed.

1981; low light levels, Bodungen et al., 1986). Resting spore flux events are common at the termination of an upwelling pulse, when standing stocks of biosiliceous plankton in the surface mixed layer are high and the availability of dissolved limiting nutrients has been depleted to levels that are suboptimal for reproduction or maintenance of metabolic activities (Pitcher, 1990; Smetacek, 1985).

Spore formation and consequent mass sinking is regarded as an optimal reproductive strategy favoring the survival of phytoplankton populations. When Chaetoceros encyst, they sink rapidly from the mixed layer; these rapid flux events have been recorded in sediment traps (Bodungen et al., 1986; Smetacek, 1985; Bienfang, 1981).

Once spore formation has taken place, increased bulk density and aggregation of individuals into larger particles result in accelerated vertical sinking. These spores and resting cells aggregate at a pycnocline or on the seafloor; at this stage, resting cells have a lower respiration rate, while retaining their photosynthetic capacity (French and Hargraves, 1980). This factor, as well as low light level, lower temperature, and decreased grazing intensity at depth favor survival of diatom resting cells and spores (Smetacek, 1985; French and Hargraves, 1980; Hargraves and French, 1975; Smayda and Mitchell-Innes, 1974).

Subsequent to rapid sinking, upwelling of nutrient-enriched deeper water may entrain viable resting spores (from the thermocline, from below the thermocline, or from the seafloor) and deliver them to the surface mixed layer. Chaetoceros resting cells are capable of immediate germination when provided with suitable conditions of light and nutrients for reproduction; consequently, these regenerated spores serve as seed populations for subsequent plankton blooms (Pitcher, 1990; Smetacek, 1985; Garrison, 1981).

At the scale of the population, spore formation and recycling is an optimal strategy in the competition for a temporally and spatially 
discontinuous supply of resources (light and/or dissolved nutrients; Bodungen, 1986). Because the residence time for a plume of nutrient-rich water upwelled into the surface layer is short, rapid growth potential and effective seeding strategy are critical to the success of pioneer taxa-such as Chaetoceros - which dominate phytoplankton blooms (Pitcher, 1990; Smetacek, 1985.)

Despite its benefits to the population, the spore-formation strategy has high mortality rates, because many individuals are not returned to the mixed layer and settle rapidly to the deep sea (D. Garrison, 1981; Smetacek, 1985). Chaetoceros resting spores also have a heavilysilicified test (Pitcher, 1990; French and Hargraves, 1980; see PI. 4, Fig. 2 ) which results in high preservation potential during transit to the bottom and in the sediments.

I attribute each CRSL at Site 798 to a single episode of mass flux at the termination of a local phytoplankton bloom event. I conclude that some episodes of high productivity associated with upwelling pulses at Site 798 were followed by nutrient depletion, resting-spore formation, rapid sinking flux with minimal heterotrophic grazing, and preservation of unfragmented Chaetoceros resting spores in discrete laminae within the sediments. If the interpretation is correct, each individual CRSL - and perhaps many of the more complexly-variable biosiliceous laminae with which they are associated-records a discrete episode of phytoplankton flux. By analogy to the modern environment, as monitored in sediment traps and plankton tows, the duration of each CRSL sedimentation event at Site 798 probably spanned several days to several weeks (Pitcher, 1990; Takahashi, 1986; Garrison, 1981, Bienfang, 1981).

\section{Phytoplankton Taphonomy?}

As described previously, CRSL are conspicuous for their monotaxonomic composition and for their very low degree of fragmentation. Since phytoplankton fragmentation is largely attributable to grazing by heterotrophs (M. Silver, 1991, pers. comm.), the scarcity of fragmentation may reflect minimal grazing pressures (relative to the large sedimentary flux; see interpretative arrow in Table 3 ) in the water column at Site 798 during the sedimentation of CRSL. The intervening biosiliceous laminae range widely between only highly fragmented biosilica to moderately fragmented and possessing three to five morphotaxa (Tables 2-4).

In a very general sense, the degree of variability among individual CRSL and the mixed-biosiliceous laminae with which they are associated may approximate the degree of seasonal and interannual variability observed in the modern biosiliceous sedimentary flux (Takahashi, 1986; Takahashi, 1987). Although the relationship between productivity, export flux, and water column taphonomy of phytoplankton is not well quantified in the biological literature (Peinert et al., 1989), I believe that clearly recognizable differences in morphotaxic diversity and degree of fragmentation of CRSL and associated biosiliceous laminae in the sediments at Site 798 record the impact of these processes (Tables 2-4).

\section{Foraminifer-rich Laminae}

Foraminifer-rich laminae are abundant and diverse in character. Planktic forams were readily distinguished from benthic forams by their gross morphology and wall structure (Conger et al., 1977; Lipps, 1973, 1966; Postuma, 1971).

Nine foraminifer morphotaxa are consistently recognizable (Table 2 ; Grimm, this volume). Foraminifers are generally very well preserved and are commonly uniformly distributed within the laminated diatomaceous sediment samples in which they occur. The outer walls of some foraminifers appears corroded in some BSEM images, suggesting minor dissolution. A large majority of the individuals which I observed are a streptospiral coiled form, which possesses a thin inner wall ( $2-15 \mu \mathrm{m}$ thick) of equant to finely prismatic calcite and a thick outer wall $(5-40 \mu \mathrm{m})$ of coarsely crystalline prismatic calcite (PI. 4, Figs. 3 and 4$)$.
Benthic foraminifers are distinguished by their thin test wall and their characteristic shape. Benthics are non-uniformly distributed in the samples; most benthics occur within individual fine laminae or within discrete stratal zones. I interpret that some of these taxa may be allochthonous; others may record short intervals of ecological colonization of a formerly inhospitable (anoxic) substrate. Perhaps significantly, meiofaunal bioturbation — as recognized by Kemp (1990) - was not observed in association with benthic foraminifer-enriched zones.

Additionally, 1-10-mm-thick layers of foraminifer grainstone are prominent in freshly cut cores. Sieved separates reveal that these laminae are dominated by Globigerina bulloides (T. Kheradyar, unpubl. data). Petrographic observations reveal scoured basal contacts and the presence of scarce glauconite grains. I interpret these "foram sands" as allochthonous layers (Pl. 1, Fig. 4), which were derived from zones of winnowing and stratigraphic condensation. I speculate that they may have been derived from the bathymetric highs that surround Site 798 on the Oki Ridge.

\section{"Homogenous" Intervals}

Because of their interesting compositional detail, recorded observations were strongly biased toward finely-laminated intervals. However, some of the samples are megascopically laminated in freshly cut core, yet lack well-defined internal structure or discrete fine laminae in BSEM images. Intervals of this sort are generally composed of diatomaceous clay and diatomaceous silty clay, in which the biosiliceous morphotaxa were highly fragmented. In sum, the composition and fabric of these intervals in BSEM intervals is monotonous.

As a working hypothesis, I propose that the relative degree of variability in composition of diatomaceous laminae reflects the variability in composition of sedimentary fluxes preserved at Site 798. If individual laminae record "snapshots" of sedimentary flux from the surface layer (Schindel, 1980), then highly variable, distinctly laminated intervals may record stronger "seasonality" in oceanic climate, than intervals that are compositionally monotonous and lack finescale variability.

\section{CONCLUSION}

The results of this pilot study validate a new methodological approach for high-resolution visual microanalysis of deep-sea sediments (Grimm, this volume; Kemp, 1990). Epoxy-impregnated and highly-polished samples of laminated hemipelagic sediment from Site 798 preserve a surprisingly high level of compositional and textural variability in BSEM images. These images permit detailed compositional assessment of individual laminae, in terms of their biogenic constituents and associated sediment types.

Given the congruence between long-term sedimentation rates with the thickness of individual laminae (Fig. 1), I interpret that some individual laminae record short-duration oceanographic and biological processes, at an annual or subannual level of temporal resolution. By reasonable comparison to modern laminated sediments and data from sediment trap studies, I conclude that a rich and highly-variable history of surface water hydrography (and seasonality) is recorded in Quaternary sediments at Site 798.

Chaetoceros resting-spore laminae (CRSL) are the most distinctive and meaningful lamination type; each one is attributable to a very short-lived and discrete episode of phytoplankton encystment and rapid mass flux, at the termination of a single upwelling event. Furthermore, the occurrence of high seasonal and interannual variability in the composition of modern biosiliceous fluxes suggests that the morphotaxic and taphonomic variations which I observe in many BSEM images are attributable to similar, very short-term variations in surface hydrography, nutrient availability, and detrital sediment delivery.

All the data in this pilot study are presented outside of their specific stratigraphic context; this absence points the direction for further research. Future analysis of laminated samples collected in strati- 
graphic zones where prominent isotopic shifts are recorded, may provide constraints upon the relationship between short-term meteorological variability and Quaternary climatic change.

\section{ACKNOWLEDGMENTS}

I am pleased to thank the ODP staff and the crew of the JOIDES Resolution for the opportunity to undertake this study. I wish to thank Lloyd Burckle for early discussions, Jon Krupp and Wilfred Bentham at the Electron Microscope Facility (UCSC) for technical assistance, and R. E. Garrison, K. Kelts, and K. Pisciotto for careful and very helpful reviews. Funding from TAMU-20413.

\section{REFERENCES}

Allredge, A. L., and Silver, M., 1988. Characteristics, dynamics and significance of marine snow. Progr. Oceanogr., 20:41-82.

Anderson, R. Y., Gardner, J. V., and Hemphill-Haley, E., 1987. Persistent late Pleistocene-Holocene seasonal upwelling and varves off the coast of California. Quat. Res., 28:307-313.

Anderson, R. Y., Linsley, B. K., and Gardner, J. V., 1990. Expression of seasonal and ENSO forcing in climatic variability at lower than ENSO frequencies: evidence from Pleistocene marine varves off California. Palaeogeogr, Palaeoclimatol., Palaeoecol., 78:287-300.

Berger, W. H., Smetacek, V. S., and Wefer, G., 1989. Productivity of the Ocean: Present and Past: New York (Wiley).

Bienfang, P. K., 1981. Sinking rates of heterogenous, temperate phytoplankton populations. J. Plankton Res., 3:235-253.

Bodungen, B. V., Smetacek, V. S., Tilzer, M. M., and Zeitzschel, B., 1986. Primary production and sedimentation during spring in the Antarctic Peninsula region. Deep-Sea Res. Part A, 33:177-194.

Bruland, K. W., Bienfang, P. K., Bishop, J.K.B., Eglinton, G., Ittekkot, V.A.W. Lampitt, R., Sarnthein, M., Thiede, J., Walsh, J. J., and Wefer, G., 1989. Group report: flux to the seafloor. In Berger, W. H., Smetacek, V. S., and Wefer, G., 1989. Productivity of the Ocean: Present and Past: New York (Wiley), 193-215.

Conger, S. D., Green, H. W., II, and Lipps, J. H., 1977. Test ultrastructure of some calcareous foraminifera. J. Foraminiferal Res., 7:278-296.

Dean, W. E., Anderson, R. Y., Arthur, M. A., Bradbury, J. P., Hay, B. J., Neff, E. D., and Wakeham, S. G., 1991. Varved sediment records of the Little Ice Age from Elk Lake, Minnesota and the Black Sea. Eos, 72:U66.

Deuser, W. G., 1986. Seasonal and interannual variations in deep-water particle fluxes in the Sargasso Sea and their relation to surface hydrography. Deep-Sea Res. Part A, 33:225-246.

Eppley, R. W., and Strickland, J.D.H., 1968. Kinetics of marine phytoplankton growth. In Droop, M. R., and Wood, E.J.F. (Eds.), Advances in Microbiology of the Sea Droop: London (Academic Press), 1:23-62.

Flügel, E., 1982. Microfacies Analysis of Limestones: New York (Springer-Verlag).

French, F., and Hargraves, P., 1980. Physiological characteristics of planktonic diatom resting spores. Mar. Biol. Lett., 1:185-195.

Garrison, D. L., 1981. Monterey Bay phytoplankton. II. Resting spore cycles in coastal diatom populations. J. Plankton Res., 3:137-156.

Goldstein, J. N., Newbury, D. E., Echlin, P., Joy, D. C., Fiori, C., and Lifshin, E., 1981. Scanning Electron Microscopy and X-Ray Microanalysis: New York (Plenum Press).

Hargraves, P. E., French, F., 1975. Observations on the survival of diatom resting spores. Nova Hedwigia, 53:229-239.

Hay, B. J., 1988. Sediment accumulation in the central western Black Sea over the past 5100 years. Paleoceanography, 3:491-508.

Hay, B. J., Honjo, S., Kempe, S., Ittekkot, V. A., Degens, E. T., Konuk, T., and Izdar, E., 1990. Interannual variability in particle flux in the southwestern Black Sea. Deep-Sea Res. Part A, 37:911-928.

Hay, W. W., 1990. Paleoceanography: a review for the GSA Centennial. Geol. Soc. Am. Bull., 100:1957-1970.
Honjo, S., 1982. Seasonality and interaction of biogenic and lithogenic particulate flux at the Panama Basin. Science, 218:883-884.

Horowitz, A., and Potter, P. E., 1971. Introductory Petrography of Fossils: New York (Springer-Verlag).

Ingle, J. C., Jr., Suyehiro, K., von Breymann, M. T., et al., 1990. Proc. ODP, Init. Repts., 128: College Station, TX (Ocean Drilling Program).

Kemp, A.E.S., 1990. Sedimentary fabrics and variation in lamination style in Peru continental margin upwelling sediments. In Suess, E., von Huene, R., et al., Proc. ODP, Sci. Results, 112: College Station, TX (Ocean Drilling Program), 43-58.

Krinsley, D. H., and Manley, C. R., 1989. Backscattered electron microscopy as an advanced technique in petrography. J. Geol. Educ., 37:202-208.

Lipps, J. H., 1973. Test structure in foraminifera. Ann. Rev. Microbiol., 27:471-488.

Lipps, J. H., 1966. Wall structure, systematics, and phylogeny studies of Cenozoic planktonic foraminifera. J. Paleontol., 40:1257-1274.

Mazzullo, J. M., Meyer, A., and Kidd, R., 1987. New sediment classification scheme for the Ocean Drilling program. In Mazzullo, J., and Graham, A. G. (Eds.), Handbook for Shipboard Sedimentologists. ODP Tech. Note, 8:45-67.

Parsons, T. R., Takahashi, M., and Hargrove, B., 1984. Biological Oceanographic Processes (3rd ed.): New York (Pergamon Press).

Peinert, R., von Bodungen, B., and Smetacek, V. S., 1989. Food web structure and loss rate. In Berger, W. H., Smetacek, V. S., and Wefer, G. (Eds.), Productivity of the Ocean: Present and Past: New York (Wiley).

Piskaln, C. H., and Johnson, T. C., 1991. Seasonal signals in Lake Malawi sediments, East Africa. Limnol. Oceanogr., 36:544-557.

Pitcher, G. C., 1990. Phytoplankton seed populations of the Cape Peninsula upwelling plume, with particular reference to resting spores of Chaetoceros (Bacillariophycae) and their role in seeding upwelling waters. Estuarine, Coastal Shelf Sci., 31:283-301.

Postuma, J. A., 1971. Planktonic Foraminifera: New York (Elsevier).

Pye, K., and Krinsley, D. H., 1984. Petrographic examination of sedimentary rocks in the SEM using backscattered electron detectors. J. Sediment. Petrol., 54:877-888.

Reimers, C. E., Lange, C. B., Tabak, M., Bernhard, J.'M., 1990. Seasonal spillover and varve formation in the Santa Barbara Basin. California. Limnol. Oceanogr., 35:1577-1585.

Schindel, D. E., 1980. Microstratigraphic sampling and the limits of paleontologic resolution. Paleobiology, 6:408-426.

Smayda, T. J., and Mitchell-Innes, B., 1974. Dark survival of autotrophic, planktonic marine diatoms. Mar. Biol., 25:195-202.

Smetacek, V. S., 1985. Role of sinking in diatom life-history cycles: ecological, evolutionary and geological significance. Mar. Biol., 84:239-251.

Soutar, A., and Crill, P. A., 1977. Sedimentation and climatic patterns in the Santa Barbara Basin during the 19th and 20th centuries. Geol. Soc. Am. Bull., 88:1161-1172.

Soutar, A., Johnson, S. R., and Baumgartner, T., 1981. In search of modern depositional analogs to the Monterey Formation. In Garrison, R. E., Douglas, R. G., Pisciotto, K. E., Isaacs, C. M., and Ingle, J. C. (Eds.), The Monterey Formation and Related Siliceous Rocks of California. Soc. Econ. Paleontol. Mineral., Pac. Sect., 123-148.

Takahashi, K., 1986. Seasonal fluxes of pelagic diatoms in the subarctic Pacific, 1982-1983. Deep-Sea Res. Part A, 33:1225-1251.

1987. Response of subarctic Pacific diatom fluxes to the 19821983 El Niño Disturbance. J. Geophys. Res., 92:14387-14392.

White, S. H., Shaw, H. F., and Huggett, J. M., 1984. The use of back-scattered electron imaging for the petrographic study of sandstones and shales. $J$. Sediment. Petrol., 54:487-494.

Date of initial receipt: 20 May 1991

Date of acceptance: 24 Jan 1992

Ms 127/128B-157 


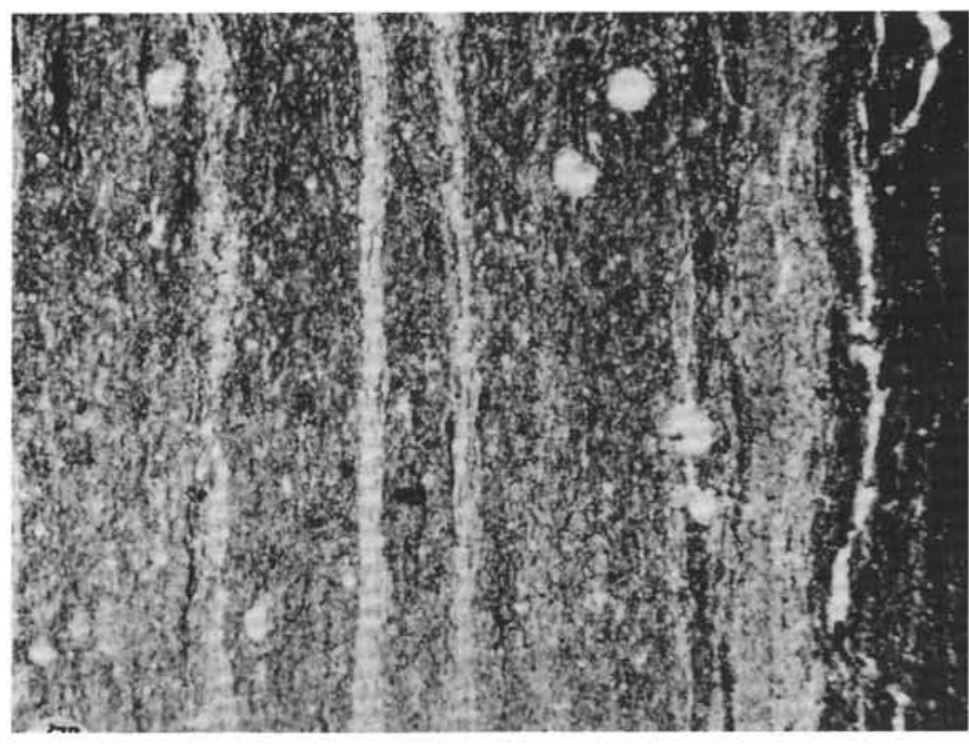

1

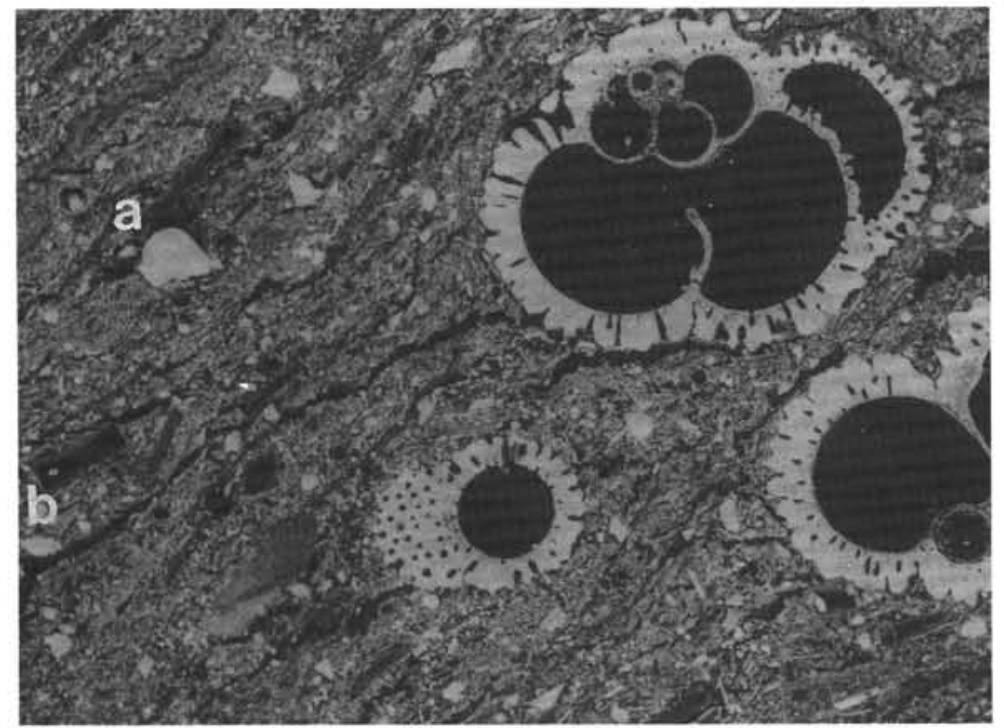

3

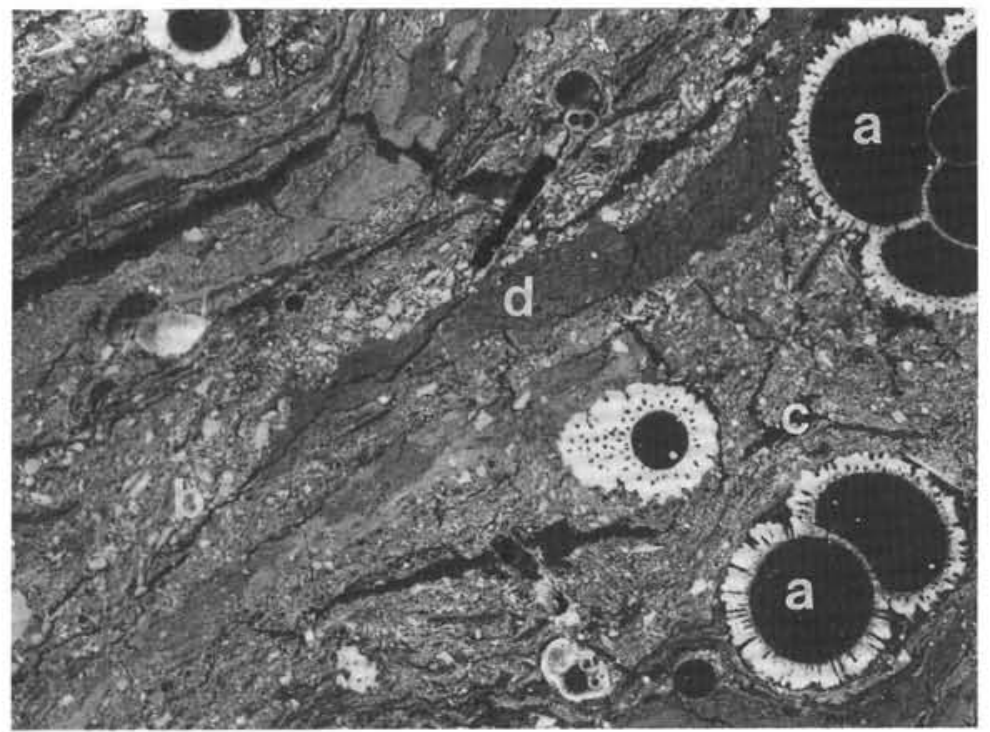

2 $\overline{100 \mu}$

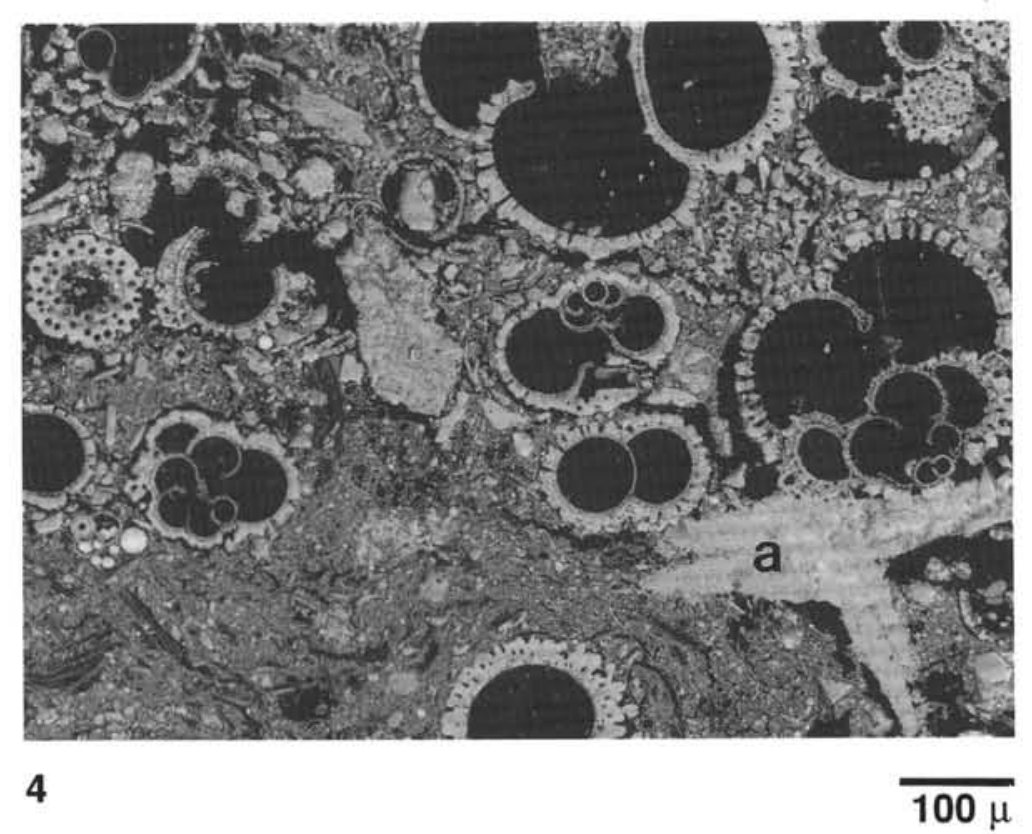

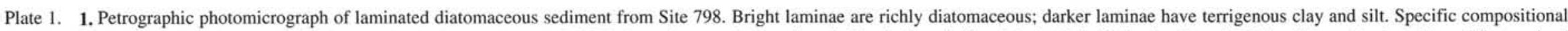

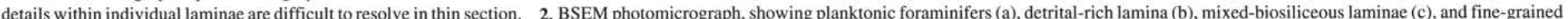

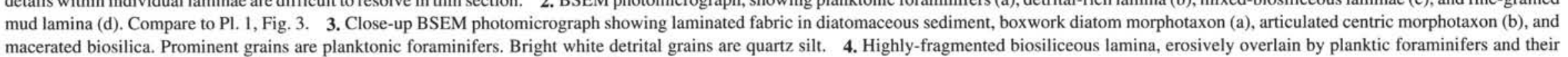
fragments; stratigraphic top is at the upper-right corner. Crystal forms (a) $=\mathrm{CaSO}_{4}$. 


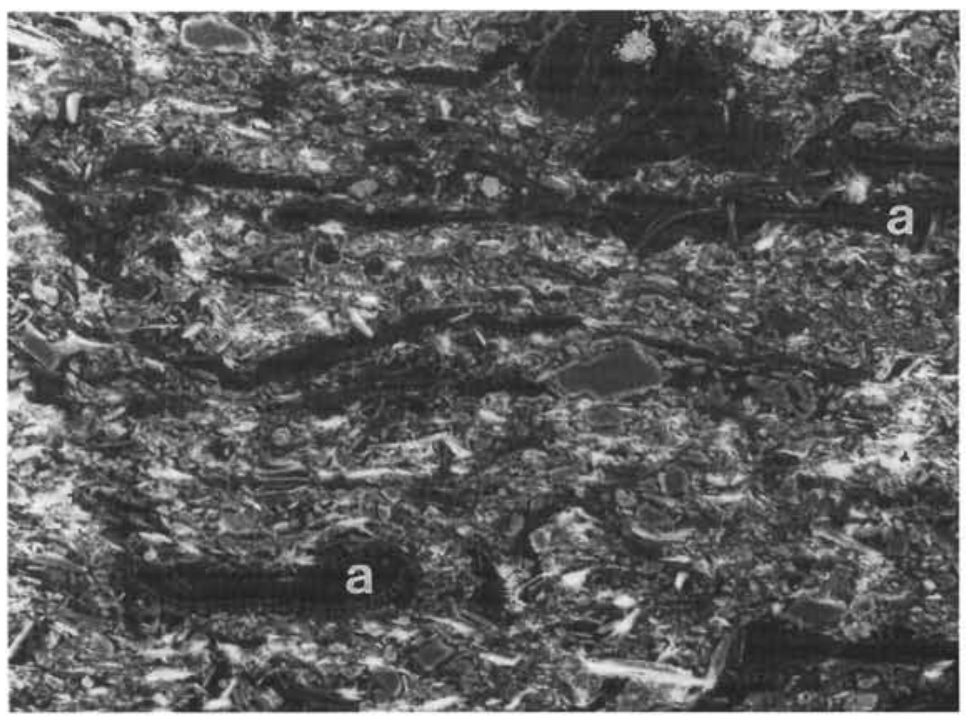

1

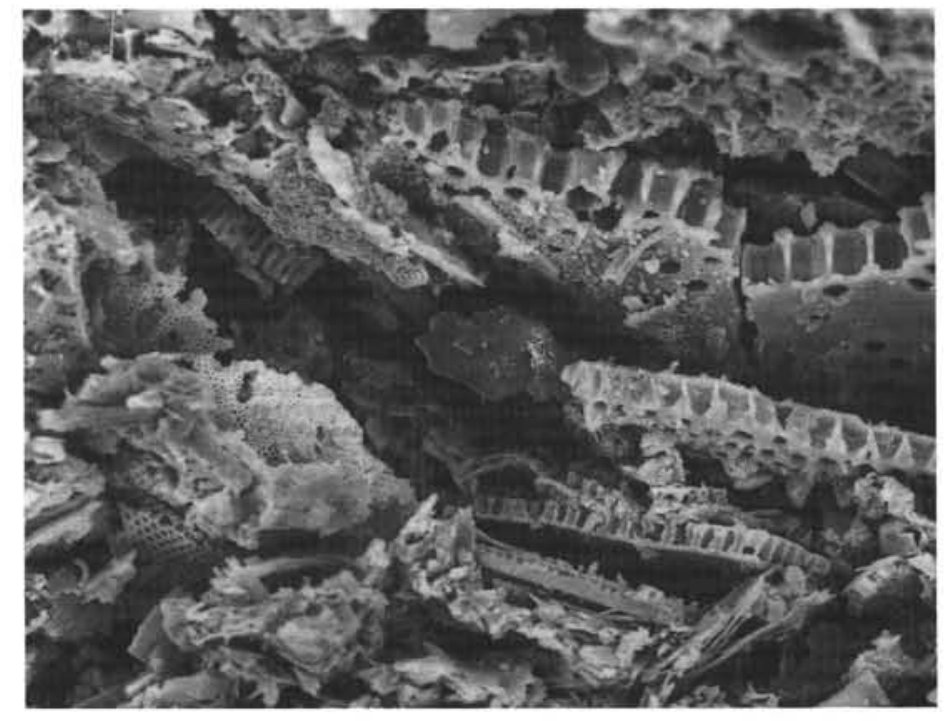

3

$\overline{20 \mu}$

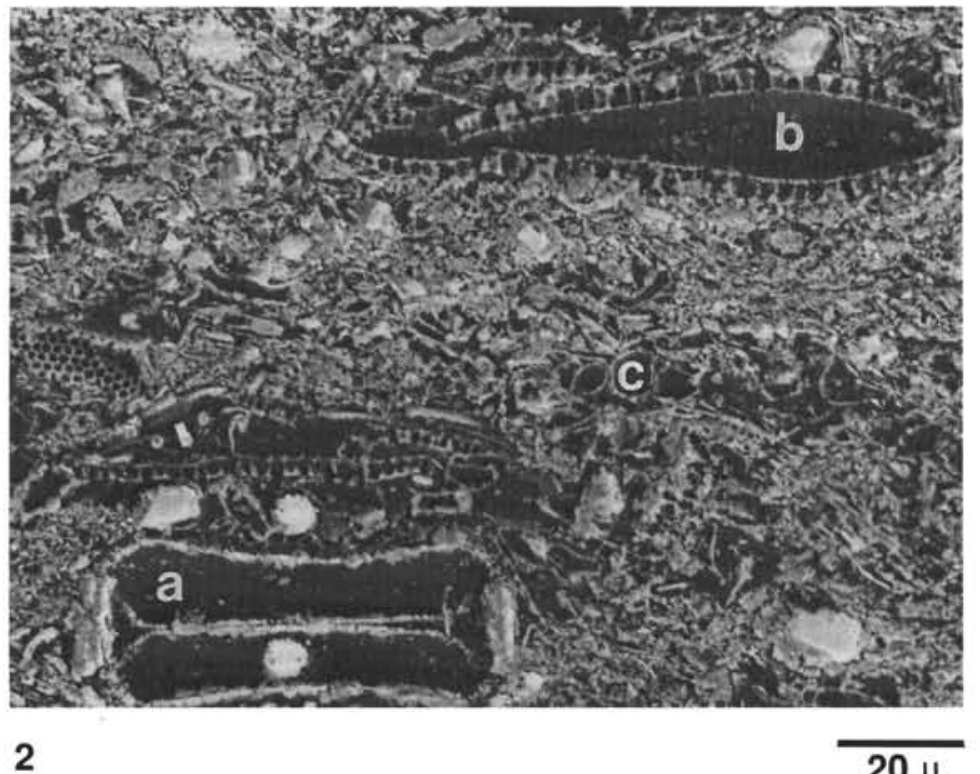

2

$20 \mu$

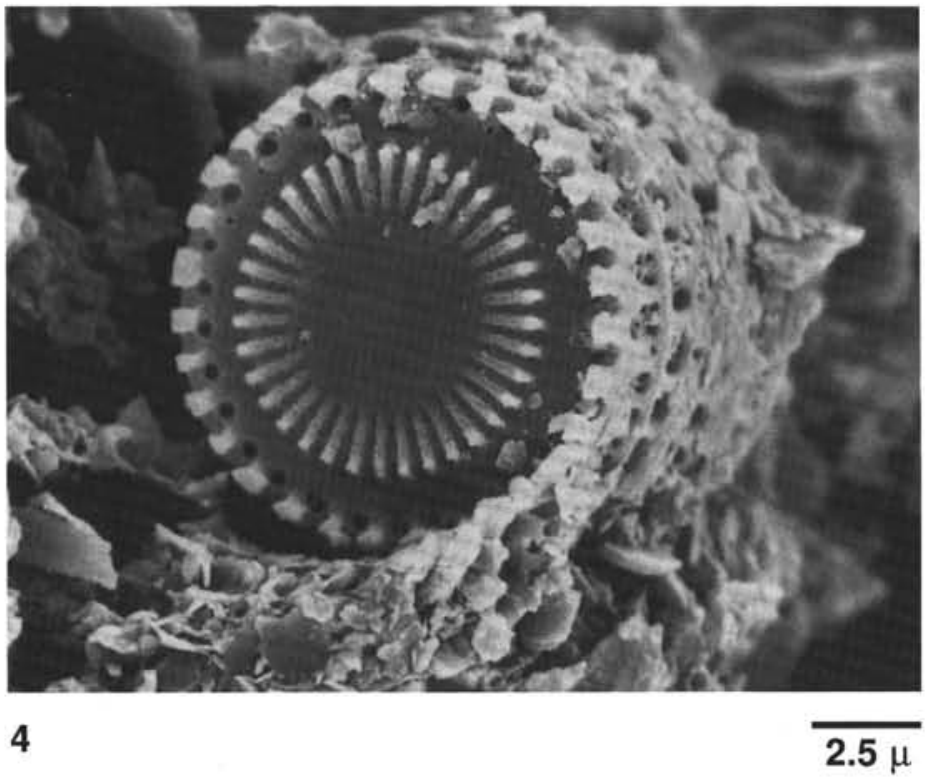

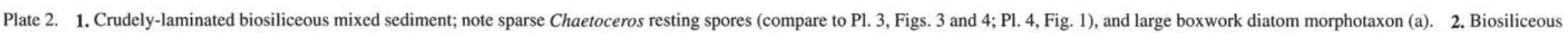

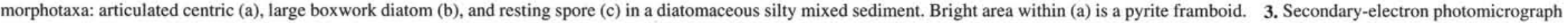

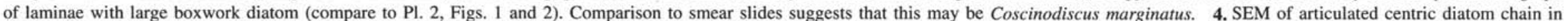
diatomaceous clay. Probable identity is Melosira, a nearshore, benthic taxon. Its presence at Site 798 suggests a coastal influence on sedimentation. 


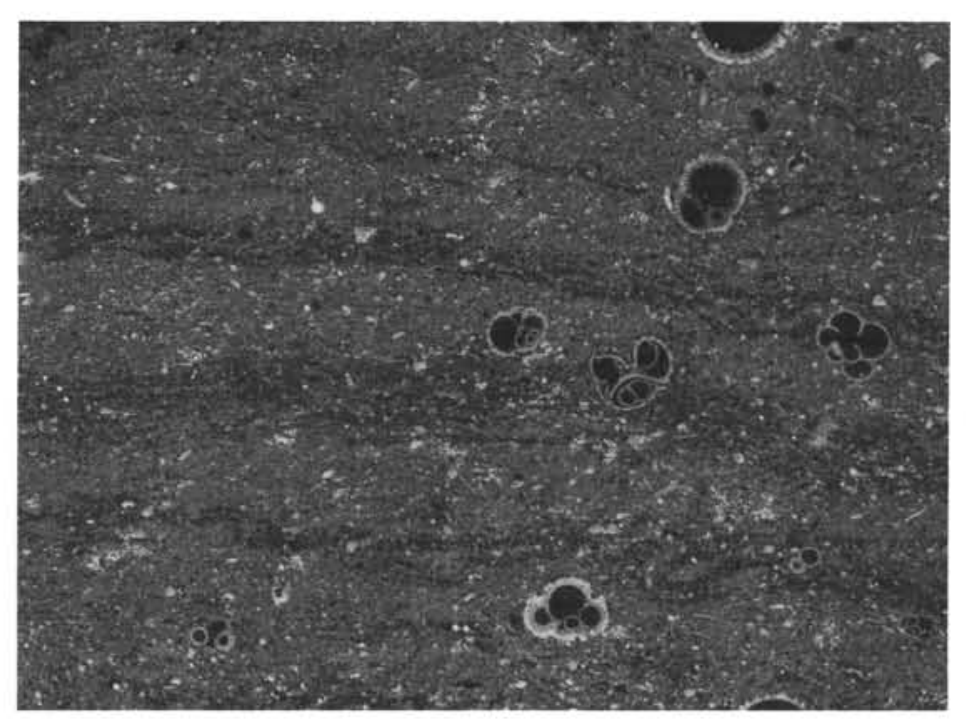

1

$\overline{200 \mu}$

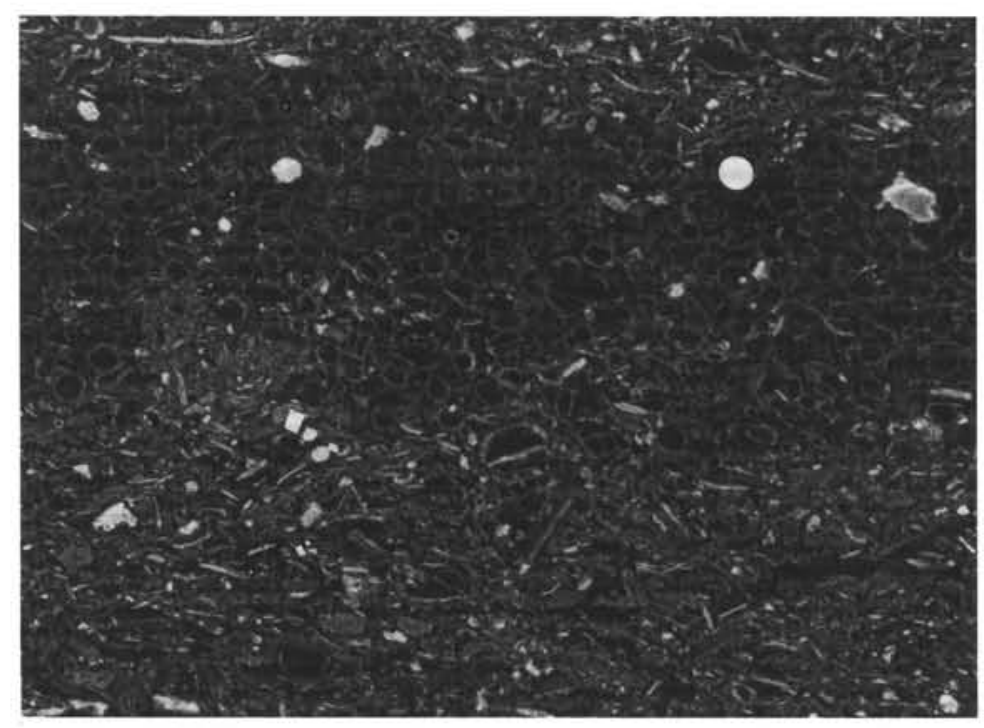

3

$\overline{20 \mu}$

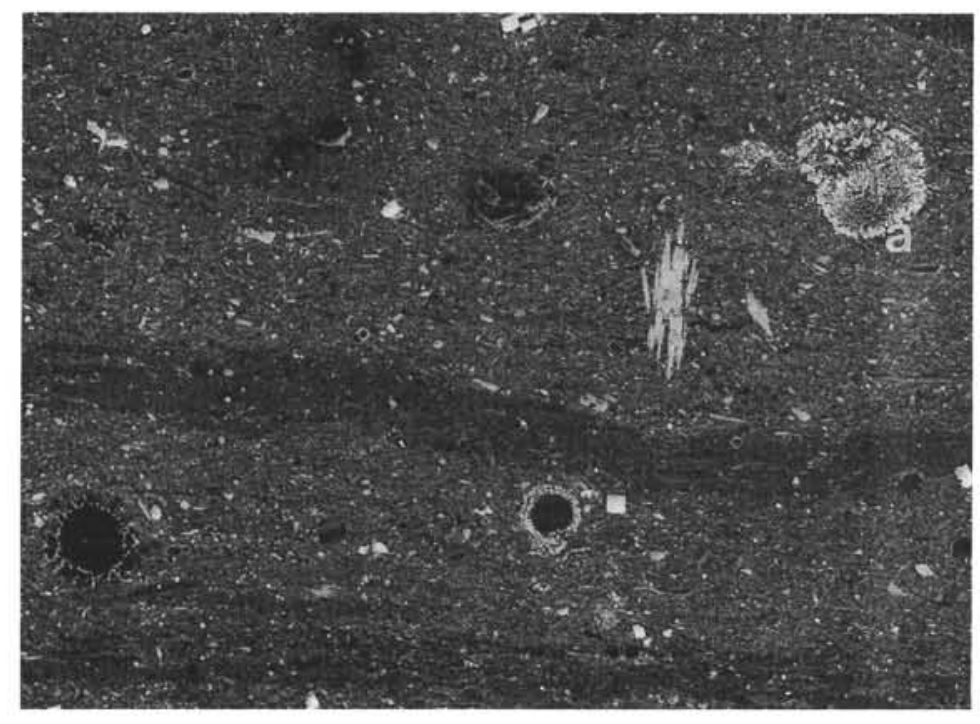

2

$\overline{100 \mu}$

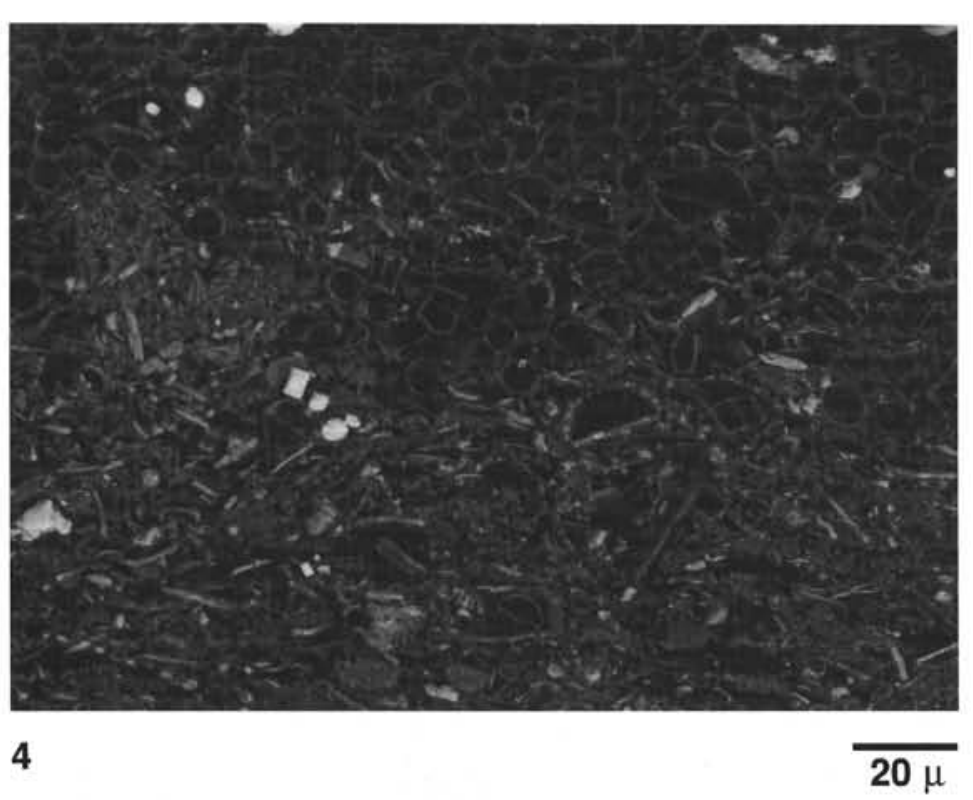

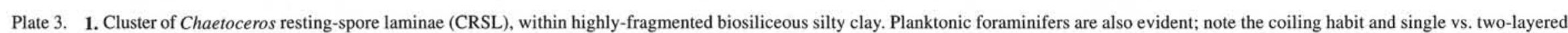

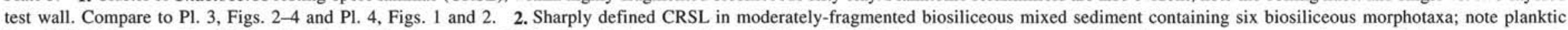

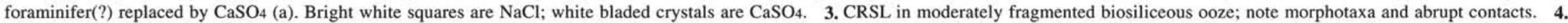
Contact between CRSL above moderately-fragmented biosiliceous mixed sediment. Note contrast in morphotaxic diversity and degree of fragmentation. 


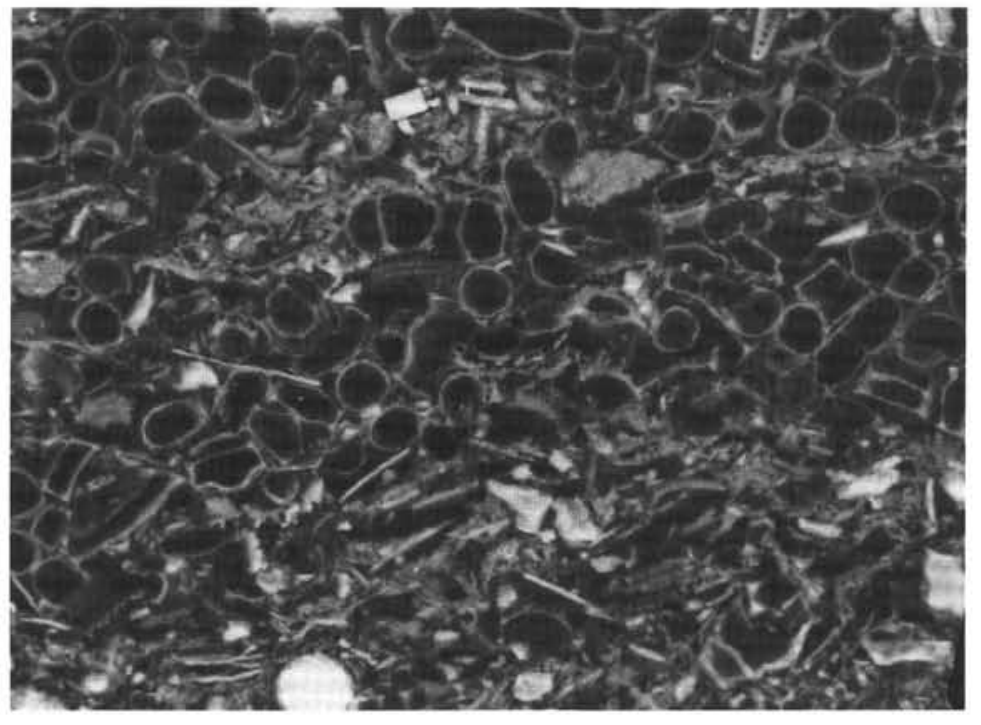

1
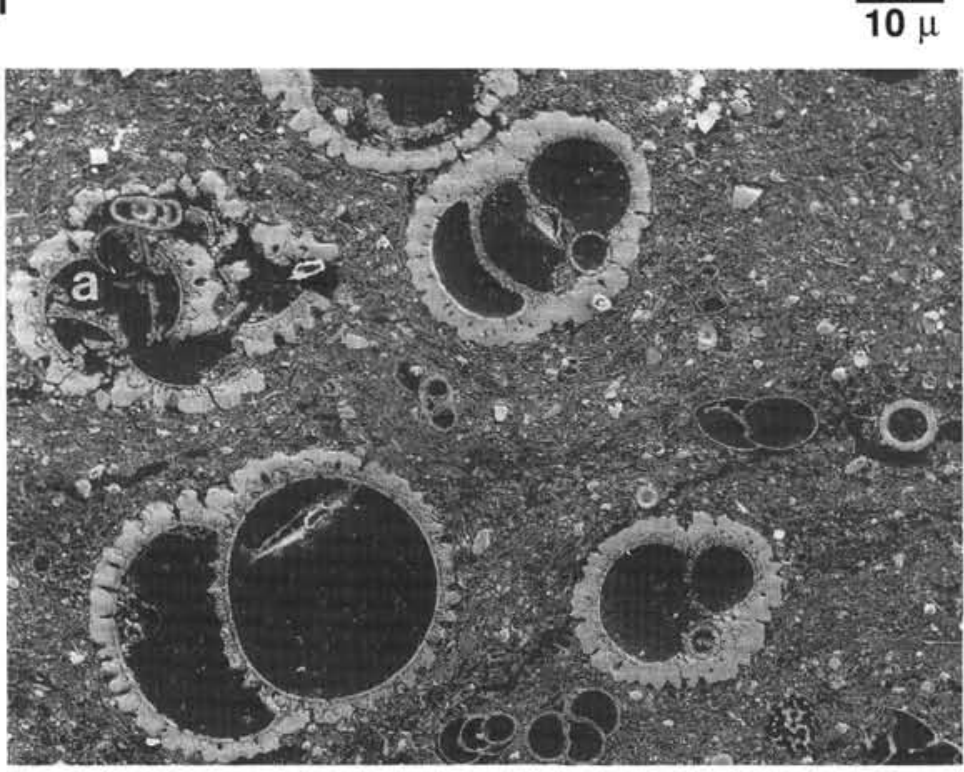

3

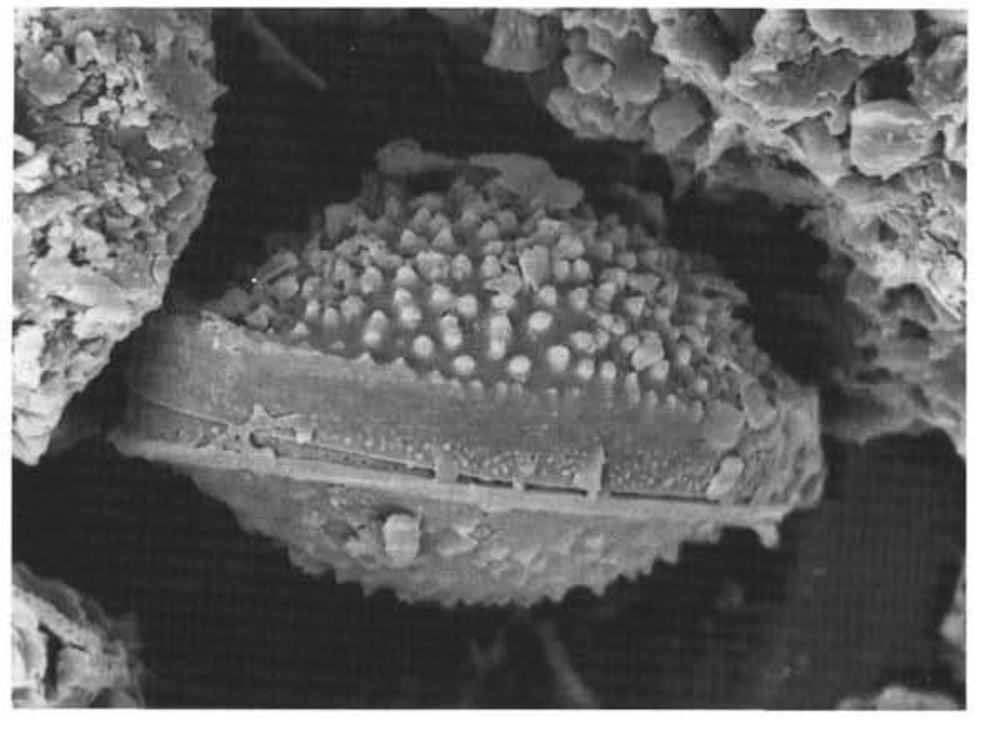

2

$5 \mu$

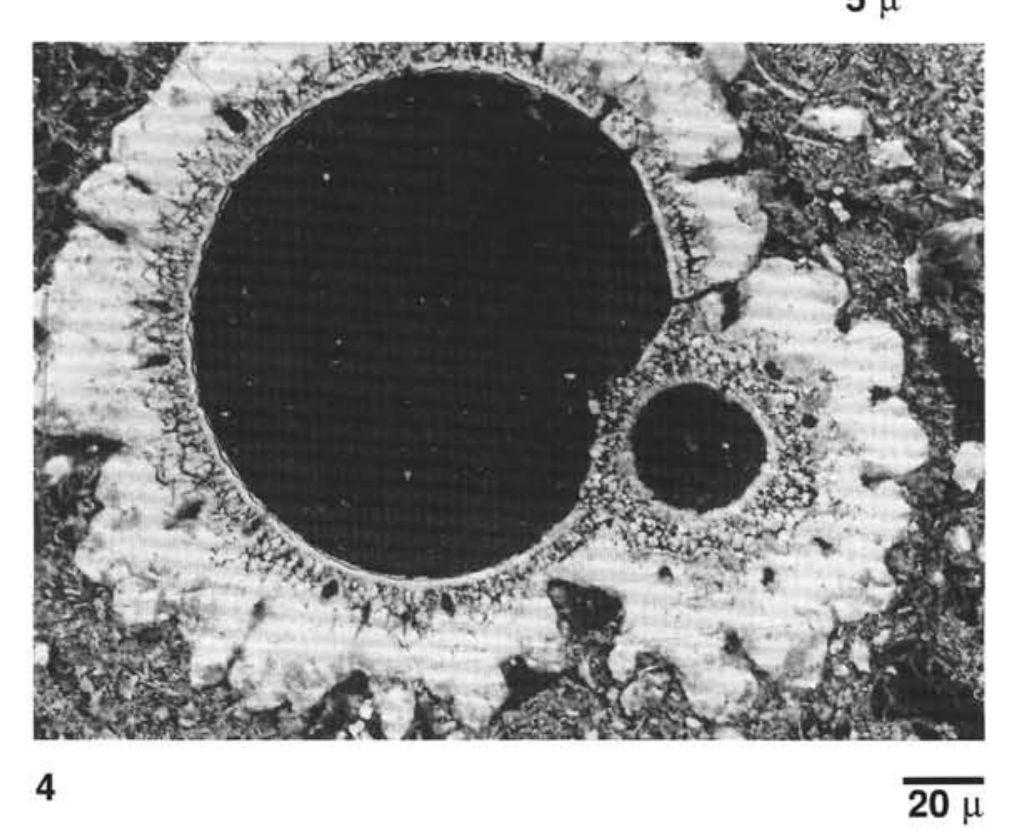

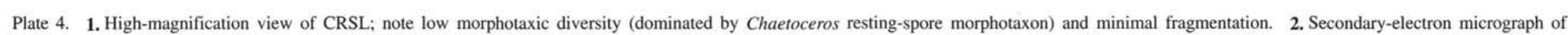
Chaetoceros resting spore. Note the heavily-silicified valves, which promote rapid sinking and high preservation potential. 3 . Thick-walled planktonic foram in unlaminated, moderately to highly fragmented biosiliceous ooze. Note two-layered test wall, fragmented test (a), and smaller, thin-walled uniserial forms. 4. Section through planktonic foraminifer morphotaxon, showing thick, two-layered calcareous wall. 


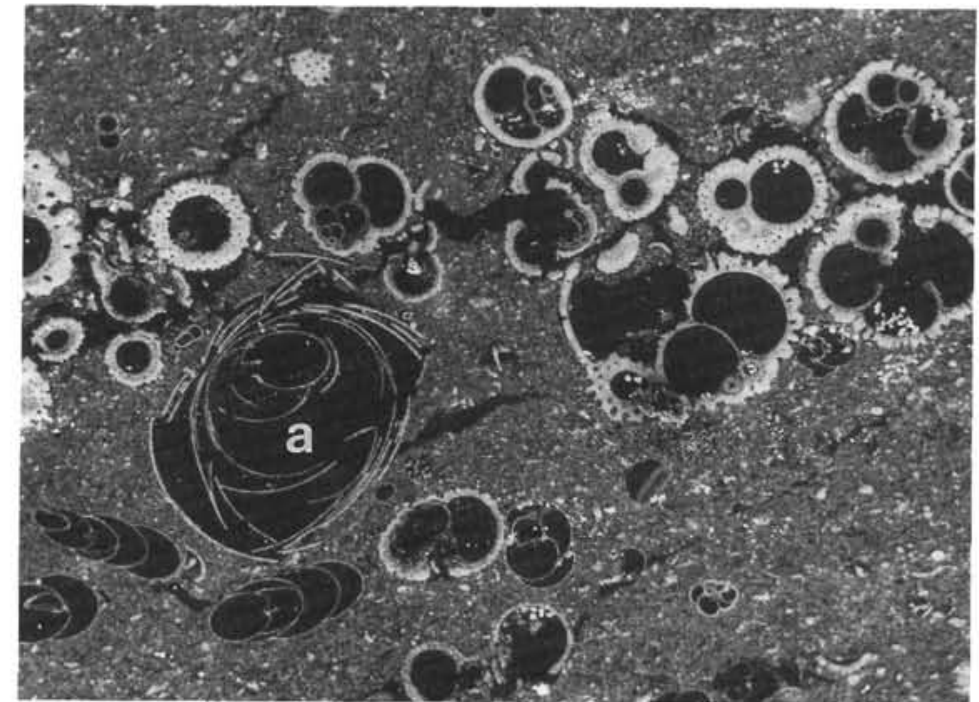

1

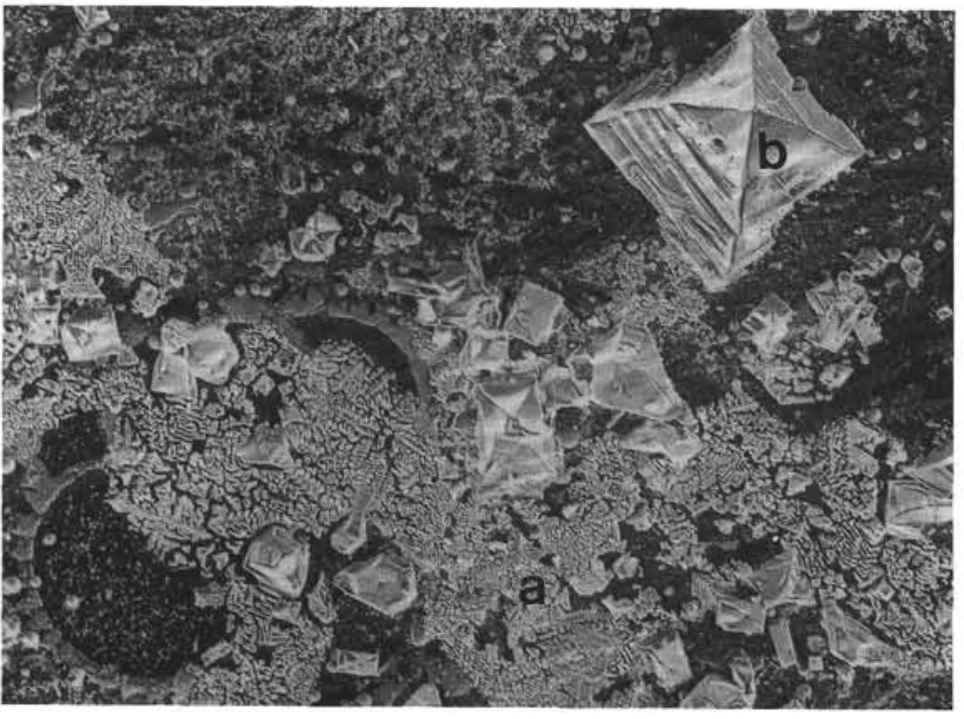

3

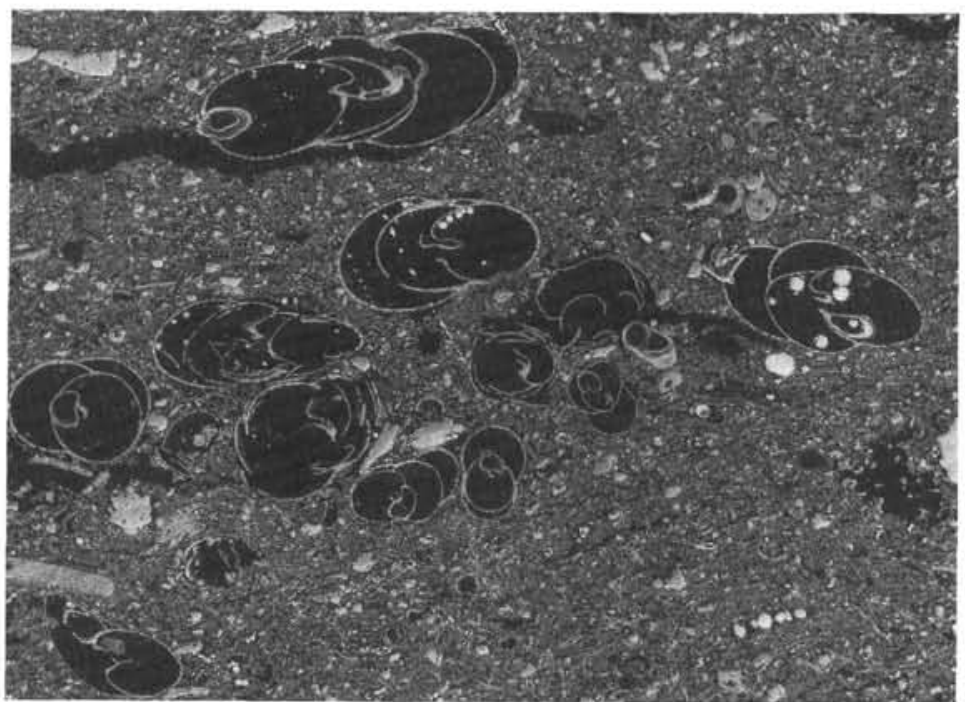

2

$\overline{100 \mu}$

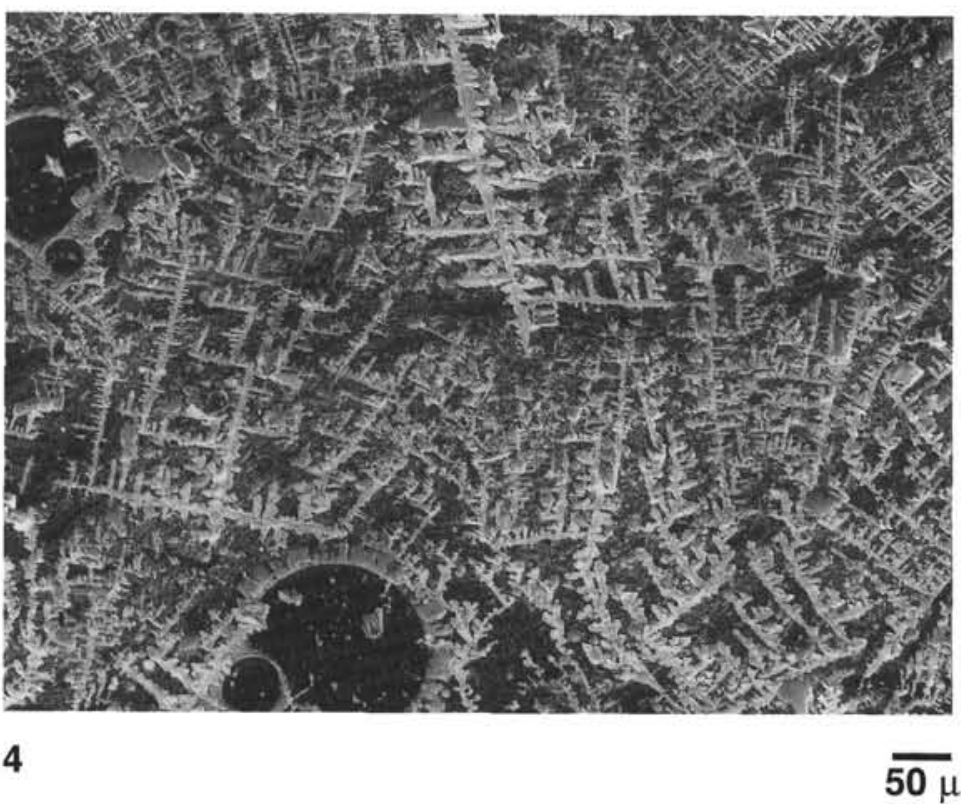

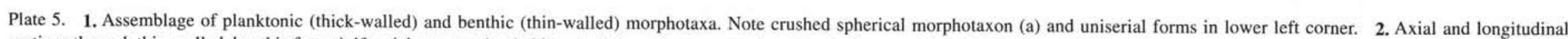
sections through thin-walled, benthic foraminifer-rich stratum (probably = Bolivina, a low oxygen taxon). 3. Chevron-shaped CaSO 4 crystals (a) and cross-section through cubic crystals of $\mathrm{NaCl}$ (b) within

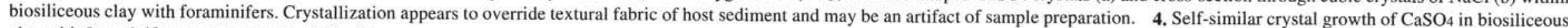
clay with foraminifers; compare to PI. 5, Fig. 3. 